\section{University of New Hampshire}

Carsey School of Public Policy

\section{CARSEY}

National Issue Brief \#76
RESEARCH

Fall 2014

\title{
Cause for Optimism? Child Poverty Declines for the First Time Since Before the Great Recession
}

\section{Patterns Across America}

\author{
Marybeth J. Mattingly, Jessica A. Carson, and Andrew Schaefer
}

$\mathrm{N}$ ew data released on September 18, 2014, by the U.S. Census Bureau indicate that child poverty fell by 0.4 percentage point between 2012 and 2013, to 22.2 percent. Though still significantly higher than in 2007 when the Great Recession hit (18.0 percent), and higher than at its conclusion (20.0 percent) in 2009, the decline from 2012 may be cause for optimism. Estimates suggest the number of poor children declined by roughly 300,000 between 2012 and 2013.

Child poverty fell in every region except the Northeast, where the rate was already lowest. These declines were largely driven by changes in urban America, where child poverty fell by 0.5 percentage point. In contrast, there was no significant change in the child poverty rate in rural or suburban places (for place definitions, see Box 1). Child poverty remains highest in urban places (29.1 percent), followed by rural places (26.2 percent). Child poverty is lowest in the suburbs (17.2 percent), though these areas are home to more of our nation's poor children than are urban or rural places.

\section{Child Poverty by State and Place}

Child poverty declined significantly in ten states: Alaska, Colorado, Florida, Hawaii, Maine, Michigan, New Hampshire, Ohio, Texas, and Wyoming. In contrast, it increased in three states: New Jersey, New Mexico, and West Virginia (see Table 1 and Map 1). With more than one-third of its children living in poverty, Mississippi continues to have the highest child poverty rate (34.0 percent), 2.8 percentage points higher than the next highest state (New Mexico).

\section{KEY FINDINGS}

For the first time since before the onset of the Great Recession in 2007, child poverty fell across America. According to the 2013 American Community Survey released on September 18, 2014, 22.2 percent of children were poor in 2013, down 0.4 percentage point since 2012. However, the latest rate still remains higher than in 2007 (18.0 percent).

The drop in child poverty between 2012 and 2013 was largely driven by declines in urban America. There was no significant change in rural or suburban places. However, there were wide variations across states in poverty by place- - some states saw significant growth in urban or rural poverty while others saw sharp declines.

Child poverty remains highest in urban places (29.1 percent), followed by rural places (26.2 percent). Suburban poverty (17.2 percent) is lowest, but more poor children reside in the suburbs than in urban or rural places.

More than half (51.8 percent) of rural black children are growing up in poverty, while just over one in five (20.5 percent) such non-Hispanic white children are poor.

Young child poverty also fell slightly, but it remains significantly higher than it was in 2009, the year in which the economy stopped shrinking and the Great Recession officially ended. In 2013, nearly one in four young children was growing up in poverty.

Poverty fell for all racial-ethnic groups except among nonHispanic whites. Declines were highest among Hispanics, Asians, and those of other or multiple races. The decline in black child poverty was smaller. 


\begin{tabular}{|c|c|c|c|c|c|c|c|c|c|c|c|c|}
\hline & \multicolumn{3}{|c|}{ ALL PLACES } & \multicolumn{3}{|c|}{ RURAL } & \multicolumn{3}{|c|}{ SUBURBAN } & \multicolumn{3}{|c|}{ URBAN } \\
\hline & $\begin{array}{c}\text { PERCENT } \\
\text { P00R } \\
2013 \\
\end{array}$ & $\begin{array}{l}\text { CHANGE } \\
\text { SINCE } \\
2012 \\
\end{array}$ & $\begin{array}{l}\text { CHANGE } \\
\text { SINCE } \\
2009 \\
\end{array}$ & \begin{tabular}{|c} 
PERCENT \\
POOR \\
2013 \\
\end{tabular} & $\begin{array}{l}\text { CHANGE } \\
\text { SINCE } \\
2012 \\
\end{array}$ & $\begin{array}{c}\text { CHANGE } \\
\text { SINCE } \\
2009 \\
\end{array}$ & $\begin{array}{c}\text { PERCENT } \\
\text { P00R } \\
2013 \\
\end{array}$ & $\begin{array}{l}\text { CHANGE } \\
\text { SINCE } \\
2012 \\
\end{array}$ & $\begin{array}{c}\text { CHANGE } \\
\text { SINCE } \\
2009 \\
\end{array}$ & \begin{tabular}{|c} 
PERCENT \\
POOR \\
2013 \\
\end{tabular} & $\begin{array}{l}\text { CHANGE } \\
\text { SINCE } \\
2012 \\
\end{array}$ & $\begin{array}{c}\text { CHANGE } \\
\text { SINCE } \\
2009 \\
\end{array}$ \\
\hline UNITED STATES & 22.2 & -0.4 & 2.2 & 26.2 & 0.0 & 2.0 & 17.2 & 0.0 & 2.4 & 29.1 & -0.5 & 2.7 \\
\hline NORTHEAST & 19.2 & 0.0 & 2.7 & 19.9 & -0.8 & 2.5 & 12.7 & 0.3 & 2.0 & 33.0 & 0.2 & 4.9 \\
\hline MIDWEST & 20.5 & -0.4 & 1.3 & 21.4 & 0.1 & 1.1 & 14.2 & -0.5 & 1.3 & 31.7 & -0.2 & 2.1 \\
\hline SOUTH & 24.6 & -0.4 & 2.1 & 32.0 & 0.6 & 2.8 & 19.6 & 0.0 & 2.6 & 29.8 & -0.7 & 2.1 \\
\hline WEST & 22.0 & -0.5 & 2.9 & 23.7 & -0.3 & 2.5 & 19.5 & 0.0 & 3.2 & 24.9 & -1.0 & 2.8 \\
\hline ALABAMA & 27.2 & -0.3 & 2.5 & 32.7 & 0.2 & 1.5 & 21.9 & 0.9 & 4.8 & 32.0 & -1.5 & 1.6 \\
\hline ALASKA & 12.1 & -1.8 & -0.7 & 20.7 & 1.0 & 4.2 & 9.7 & 1.4 & -0.4 & 7.1 & -5.4 & -4.5 \\
\hline ARIZONA & 26.5 & -0.5 & 3.1 & 37.9 & 4.2 & 4.1 & 21.6 & 3.5 & 4.6 & 29.8 & -3.4 & 2.5 \\
\hline ARKANSAS & 29.0 & 0.5 & 1.9 & 33.5 & -0.3 & 3.1 & 22.0 & 1.7 & 0.4 & 31.4 & 0.4 & 2.5 \\
\hline CALIFORNIA & 23.5 & -0.3 & 3.6 & 23.4 & -1.9 & 3.2 & 21.8 & -0.5 & 3.7 & 25.6 & 0.2 & 3.7 \\
\hline COLORADO & 16.9 & -1.6 & -0.5 & 20.6 & -1.3 & 1.1 & 11.5 & -2.0 & -0.6 & 22.4 & -1.4 & -1.3 \\
\hline CONNECTICUT & 14.5 & -0.3 & 2.4 & 7.9 & -2.8 & -1.9 & 10.4 & 0.1 & 2.0 & 25.2 & -1.0 & 3.9 \\
\hline DELAWARE & 18.0 & 0.6 & 1.5 & & $\mathrm{~N} / \mathrm{A}$ & & 15.6 & 4.4 & 1.8 & 35.0 & 2.0 & 4.3 \\
\hline DISTRICT OF COLOMBIA & 27.2 & 0.6 & -2.3 & & $\mathrm{~N} / \mathrm{A}$ & & & $N / A$ & & 27.2 & 0.6 & -2.3 \\
\hline FLORIDA & 24.5 & -0.9 & 3.2 & 34.4 & -0.6 & 4.8 & 22.2 & -1.0 & 3.0 & 29.6 & 0.5 & 4.4 \\
\hline GEORGIA & 26.5 & -0.7 & 4.2 & 34.9 & -0.4 & 3.5 & 21.8 & -0.6 & 4.2 & 36.4 & -2.6 & 4.3 \\
\hline HAWAll & 13.3 & -3.8 & -0.5 & 21.4 & 0.1 & 7.0 & 10.8 & -2.8 & -3.5 & 12.9 & -6.4 & 1.2 \\
\hline IDAHO & 19.1 & -1.5 & 1.0 & 19.2 & -4.2 & 0.2 & 20.4 & 4.9 & 5.4 & 16.6 & -8.1 & -4.7 \\
\hline ILLINOIS & 20.7 & 0.0 & 1.8 & 21.8 & 1.0 & -0.9 & 15.6 & 0.2 & 2.6 & 29.8 & 0.4 & 2.7 \\
\hline INDIANA & 22.2 & -0.2 & 2.3 & 21.3 & -1.3 & 0.7 & 15.6 & -0.2 & 2.8 & 32.5 & 0.4 & 2.0 \\
\hline IOWA & 16.2 & 0.3 & 0.5 & 17.3 & -0.3 & 1.7 & 7.9 & -1.9 & -0.9 & 23.5 & 4.1 & 0.7 \\
\hline KANSAS & 18.7 & -0.4 & 1.0 & 20.6 & -1.3 & 1.3 & 11.0 & -1.1 & -0.1 & 24.8 & 0.6 & 1.2 \\
\hline KENTUCKY & 25.3 & -1.3 & -0.3 & 30.8 & -1.9 & -1.1 & 19.5 & 0.3 & 0.7 & 24.3 & -2.9 & -0.7 \\
\hline LOUISIANA & 27.7 & -0.4 & 3.5 & 35.1 & 4.6 & 5.4 & 22.6 & -0.5 & 3.8 & 33.6 & -0.5 & 5.8 \\
\hline MAINE & 17.7 & -3.2 & 0.6 & 19.7 & -4.0 & 0.0 & 13.4 & -0.9 & 1.8 & 27.3 & -5.9 & 0.7 \\
\hline MARYLAND & 13.6 & -0.2 & 2.0 & 23.6 & 9.9 & 8.7 & 10.6 & -0.2 & 1.8 & 24.0 & -3.8 & 0.6 \\
\hline MASSACHUSETTS & 16.3 & 0.9 & 3.2 & 18.6 & $\mathrm{~N} / \mathrm{A}$ & & 13.0 & 1.1 & 3.1 & 30.5 & 3.7 & 6.4 \\
\hline MICHIGAN & 23.8 & -1.1 & 1.3 & 25.0 & 1.2 & 2.3 & 16.1 & -1.4 & 1.2 & 39.8 & -1.6 & 2.7 \\
\hline MINNESOTA & 14.0 & -0.5 & 0.0 & 16.0 & -1.0 & 0.0 & 10.5 & 0.5 & 1.4 & 20.9 & -1.7 & -2.3 \\
\hline MISSISSIPPI & 34.0 & -0.7 & 3.0 & 39.6 & -0.9 & 1.8 & 20.9 & -1.3 & 2.0 & 47.7 & 1.9 & 14.9 \\
\hline MISSOURI & 22.2 & -0.4 & 1.5 & 30.0 & 2.9 & 3.7 & 15.2 & -1.8 & 0.1 & 31.7 & -0.3 & 2.7 \\
\hline MONTANA & 21.3 & 1.0 & -0.1 & 22.9 & 1.9 & 0.6 & 12.1 & 0.1 & 1.0 & 22.4 & -0.6 & -2.3 \\
\hline NEBRASKA & 17.7 & -0.2 & 2.4 & 17.4 & -0.1 & 2.3 & 8.5 & -3.2 & 0.3 & 24.2 & 1.6 & 4.9 \\
\hline NEVADA & 22.7 & -1.3 & 5.1 & 22.1 & 0.8 & 8.4 & 21.4 & -1.2 & 5.1 & 23.8 & -2.2 & 4.1 \\
\hline NEW HAMPSHIRE & 10.2 & -5.3 & -0.6 & 11.8 & -6.7 & 0.1 & 6.3 & -3.2 & -1.0 & 19.5 & -9.5 & -0.8 \\
\hline NEW JERSEY & 16.7 & 1.3 & 3.2 & & N/A & & 13.1 & 0.1 & 1.4 & 43.1 & 2.4 & 15.3 \\
\hline NEW MEXICO & 31.2 & 1.8 & 5.9 & 32.7 & 2.3 & 8.4 & 33.2 & 2.8 & 5.3 & 28.0 & 0.6 & 4.1 \\
\hline NEW YORK & 22.8 & 0.0 & 2.8 & 24.9 & 1.6 & 3.9 & 12.7 & 1.0 & 2.5 & 31.8 & -0.8 & 3.5 \\
\hline NORTH CAROLINA & 25.2 & -0.8 & 2.7 & 33.0 & 1.7 & 4.3 & 20.7 & -0.6 & 2.9 & 26.7 & -0.4 & 3.7 \\
\hline NORTH DAKOTA & 12.0 & -1.1 & -1.0 & 12.5 & -2.9 & -2.7 & 7.5 & 0.7 & 1.9 & 14.5 & 1.2 & 0.4 \\
\hline $\mathrm{OHIO}$ & 22.7 & -1.0 & 0.9 & 23.5 & -0.8 & 0.5 & 15.1 & -0.7 & 0.5 & 42.0 & -0.8 & 4.0 \\
\hline OKLAHOMA & 24.0 & -0.1 & 1.8 & 26.7 & -0.1 & 1.3 & 17.2 & 0.4 & 1.6 & 29.5 & -0.6 & 2.6 \\
\hline OREGON & 21.6 & -1.4 & 2.4 & 26.4 & -0.1 & 2.1 & 18.7 & -1.5 & 2.5 & 23.5 & -1.2 & 3.5 \\
\hline PENNSYLVANIA & 19.4 & -0.4 & 2.2 & 20.0 & -0.7 & 2.6 & 12.8 & -0.2 & 1.6 & 38.5 & -0.2 & 4.0 \\
\hline RHODE ISLAND & 21.5 & 2.1 & 4.7 & & $\mathrm{~N} / \mathrm{A}$ & & 16.2 & -0.5 & 0.9 & 35.9 & 10.8 & 15.8 \\
\hline SOUTH CAROLINA & 27.5 & 0.5 & 3.0 & 39.8 & 5.7 & 6.3 & 24.4 & 0.6 & 4.4 & 29.1 & 0.1 & 0.1 \\
\hline SOUTH DAKOTA & 18.6 & 1.1 & 0.1 & 22.2 & 1.5 & -0.4 & 11.9 & 4.3 & 3.4 & 17.3 & -1.4 & -0.7 \\
\hline TENNESSEE & 26.5 & 0.7 & 2.7 & 28.4 & 0.2 & 3.4 & 18.3 & 1.8 & 2.5 & 35.6 & 0.5 & 3.3 \\
\hline TEXAS & 25.0 & -0.7 & 0.6 & 29.5 & 1.0 & 2.4 & 20.0 & -0.1 & 1.4 & 29.1 & -1.4 & 0.1 \\
\hline UTAH & 14.8 & -0.4 & 2.6 & 16.3 & 2.7 & -0.1 & 12.7 & 0.0 & 3.5 & 21.8 & -4.1 & 0.5 \\
\hline VERMONT & 15.3 & -0.2 & 2.0 & 17.4 & -0.4 & 2.4 & 12.2 & 3.0 & 2.9 & & $\mathrm{~N} / \mathrm{A}$ & \\
\hline VIRGINIA & 15.7 & 0.4 & 1.8 & 23.7 & -0.8 & 1.8 & 11.2 & 0.7 & 1.6 & 24.4 & 1.3 & 3.5 \\
\hline WASHINGTON & 18.8 & 0.3 & 2.6 & 24.1 & -0.8 & 0.8 & 15.6 & 1.1 & 2.0 & 22.9 & -0.6 & 4.1 \\
\hline WEST VIRGINIA & 27.0 & 2.4 & 3.4 & 29.5 & 0.9 & 0.3 & 21.6 & 2.6 & 4.4 & 40.4 & 8.5 & 12.7 \\
\hline WISCONSIN & 18.4 & 0.2 & 1.7 & 17.1 & -0.2 & 1.2 & 10.7 & 0.7 & 1.1 & 31.4 & -0.5 & 2.6 \\
\hline WYOMING & 13.2 & -3.7 & 0.6 & 13.7 & -3.5 & 0.7 & & $\mathrm{~N} / \mathrm{A}$ & & 12.8 & -7.1 & 2.0 \\
\hline
\end{tabular}

Note: Change is displayed in percentage points and based on unrounded percentages. Results may differ slightly from those that would be obtained using rounded figures. Bold font indicates a statistically significant change $(p<0.05)$.

Source: American Community Survey, 1-Year Estimates, 2009, 2012, and 2013 
The South includes most of the nation's other highpoverty states including Alabama, Arkansas, Georgia, Louisiana, North Carolina, South Carolina, Tennessee, and West Virginia. States with historically low levels of child poverty typically continued to have the lowest rates in 2013, with the notable exception of New Jersey, where child poverty rose 1.3 percentage points in one year.

Followers of state trends may recall the dramatic increase observed in New Hampshire last year. In 2012, child poverty grew to over 15.6 percent, up 3.6 percentage points since 2011 and costing New Hampshire its rank as the state with the lowest child poverty. In 2013, with a poverty rate of 10.2 percent (down 5.3 percentage points from 2012), New Hampshire returned to the bottom of the child-poverty rankings. ${ }^{1}$ Note that the relatively small size of New Hampshire means there is great variability in the estimates, so much of the change in child poverty observed may be due to survey sampling error.

\section{Young Child Poverty by Region and Place}

Child poverty is our primary focus in this brief because of the long-term implications of experiencing poverty before age $18 .^{2}$ Research suggests that early childhood poverty is particularly harmful. Critical brain development $^{3}$ may be impeded by a lack of resources, and social science research documents the long term educational, occupational, health, and family consequences of poverty in the early years. ${ }^{4}$ Thus, poverty among young children-those under age 6-merits special attention.

Young children have long been the age group at the greatest risk of living in poverty. This remains true in the most recent data, which show about one in four young children growing up poor (24.8 percent). The rate of young-child poverty fell slightly from 2012 to 2013, as shown in Table 2, and the number of poor young children dropped by more than an estimated

\section{FIGURE 1: PERCENT OF CHILDREN IN POVERTY, 2013}

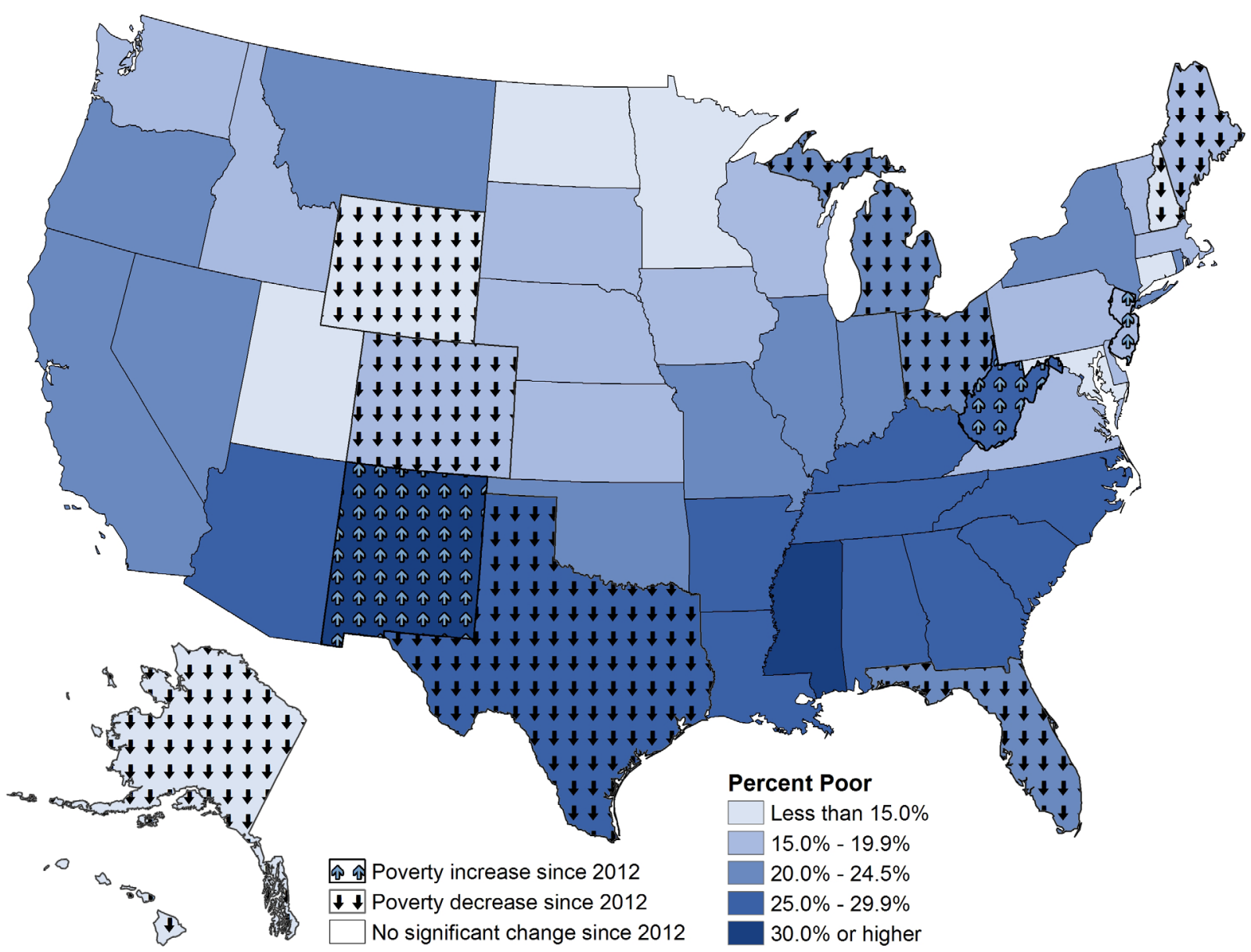




\section{TABLE 2: YOUNG CHILD POVERTY BY REGION AND PLACE TYPE IN 2013}

\begin{tabular}{|c|c|c|c|c|c|c|c|c|c|c|c|c|}
\hline & \multicolumn{3}{|c|}{ ALL PLACES } & \multicolumn{3}{|c|}{ RURAL } & \multicolumn{3}{|c|}{ SUBURBAN } & \multicolumn{3}{|c|}{ URBAN } \\
\hline & $\begin{array}{c}\text { PERCENT } \\
\text { POOR } \\
2013\end{array}$ & $\begin{array}{c}\text { CHANGE } \\
\text { SINCE } \\
2012\end{array}$ & $\begin{array}{c}\text { CHANGE } \\
\text { SINCE } \\
2009\end{array}$ & $\begin{array}{c}\text { PERCENT } \\
\text { POOR } \\
2013\end{array}$ & $\begin{array}{c}\text { CHANGE } \\
\text { SINCE } \\
2012\end{array}$ & $\begin{array}{l}\text { CHANGE } \\
\text { SINCE } \\
2009\end{array}$ & $\begin{array}{c}\text { PERCENT } \\
\text { POOR } \\
2013\end{array}$ & $\begin{array}{c}\text { CHANGE } \\
\text { SINCE } \\
2012\end{array}$ & $\begin{array}{c}\text { CHANGE } \\
\text { SINCE } \\
2009\end{array}$ & $\begin{array}{c}\text { PERCENT } \\
\text { POOR } \\
2013\end{array}$ & $\begin{array}{c}\text { CHANGE } \\
\text { SINCE } \\
2012\end{array}$ & $\begin{array}{c}\text { CHANGE } \\
\text { SINCE } \\
2009\end{array}$ \\
\hline UNITED STATES & 24.8 & -0.7 & 1.9 & 30.3 & 0.2 & 1.7 & 19.2 & -0.6 & 2.0 & 30.9 & -0.7 & 2.3 \\
\hline NORTHEAST & 21.5 & -0.3 & 2.6 & 23.4 & -1.2 & 1.4 & 14.7 & 0.0 & 2.1 & 33.1 & -0.3 & 4.0 \\
\hline MIDWEST & 23.4 & -1.1 & 0.8 & 24.8 & -0.5 & -0.6 & 16.3 & -1.2 & 0.9 & 34.0 & -0.7 & 2.0 \\
\hline SOUTH & 27.7 & -0.5 & 1.9 & 36.8 & 1.6 & 3.5 & 22.0 & -0.4 & 2.2 & 32.4 & -0.7 & 1.7 \\
\hline WEST & 23.5 & -1.0 & 2.3 & 27.1 & -0.4 & 2.8 & 20.7 & -0.9 & 2.4 & 26.2 & -1.0 & 2.2 \\
\hline
\end{tabular}

Note: Change is displayed in percentage points and based on unrounded percentages. Results may differ slightly from those that would be obtained using rounded figures. Bold font indicates a statistically significant change $(p<0.05)$.

Source: American Community Survey, 1-Year Estimates, 2009, 2012, and 2013

200,000. Declines in young child poverty are evident across the Midwest, South, and West as well as across America's suburban and urban places. Young children are most at risk of living in poverty in the rural South, where more than one in three children under age 6 is poor (36.8 percent). In the rural Northeast and Midwest, poverty is no longer significantly higher than in 2009, the year the Great Recession ended, though rates there remain somewhat higher than in 2007, before the recession began. ${ }^{5}$

\section{Race-Ethnicity and Nativity by Region and Place}

Poverty varies dramatically by race-ethnicity. Black child poverty is highest (39.1 percent), followed by Hispanic child poverty (32.8 percent), and child poverty among those of other or multiple races (30.4 percent). Poverty is lower among non-Hispanic whites and lowest among Asians, at 13.5 and 13.1 percent, respectively. Child poverty declined between 2012 and 2013 among all racialethnic groups except non-Hispanic whites, although blacks realized smaller declines than did Asians, Hispanics, and those of other or multiple races.

Overall child poverty is highest in urban places. Most racial-ethnic groups living in rural places experience child poverty rates similar to or higher than their urban peers. It is the lower concentration of blacks and Hispanics in rural America and relatively lower concentration of whites in urban places that account for this paradox. Non-Hispanic whites and blacks both have higher poverty in rural places than in urban places (20.5 versus 14.4 percent and 51.8 versus 45.0 percent, respectively), and poverty is only higher in urban places among Hispanics (37.1 versus 36.0 percent).
Child poverty rates by race-ethnicity also vary dramatically by region and place type. Southern black children fare the worst, with poverty at 38.8 percent, largely driven by the extremely high rate among rural Southern black children (52.8 percent). Black children in the rural Midwest also experience considerable disadvantage with a poverty rate of 43.4 percent in 2013. Black child poverty rates are also high in urban places, in the South, Northeast, and the Midwest.

We also find evidence of significant declines in poverty among children living with at least one foreign-born parent (not shown). Our analyses indicate that the poverty rate declined for these children from 27.4 percent in 2012 to 26.5 percent in 2013. As for all children, poverty among this group is highest in rural (31.5 percent) and urban (31.3 percent) places. Additionally, regional variations are evident. Children with at least one foreignborn parent have the highest poverty rates in the South and West, particularly in rural and urban places, and in urban parts of the Northeast, Midwest, and West, where the rate exceeds 30 percent in each place.

\section{Discussion}

This research shows that rural poverty remains persistently high, suggesting the importance of anti-poverty efforts that consider rural challenges, like transportation, child care, lack of jobs, and in some regions, very high heating costs. Young children continue to weather particular risk of poverty, and even with a slight decline in the aggregate rate, nearly one in four children continue to live below the poverty threshold. Given the long-term implications of early childhood poverty, solutions that target this group of vulnerable Americans, as well 
TABLE 3: CHILD POVERTY BY RACE/ETHNICITY, REGION, AND PLACE TYPE IN 2013

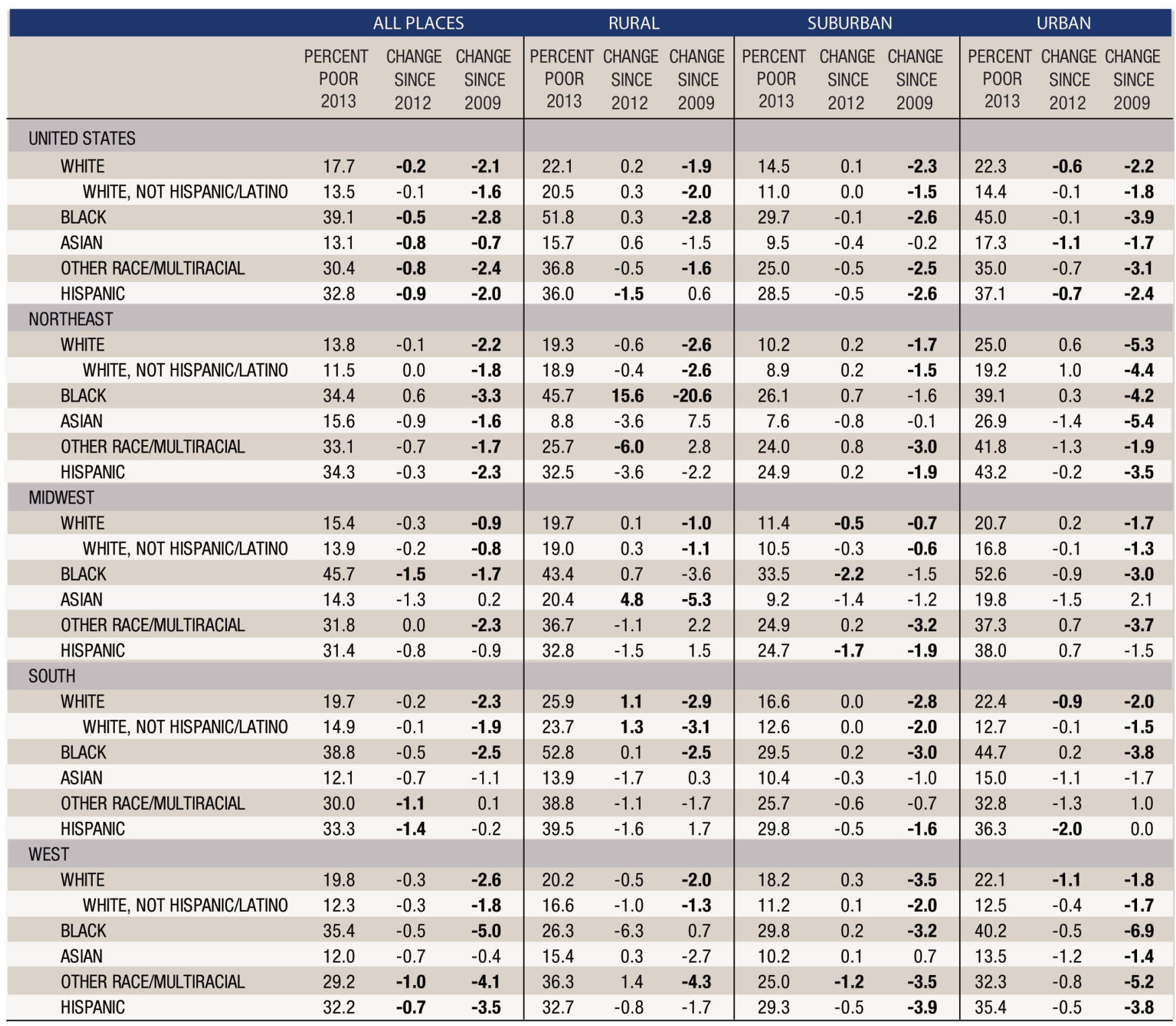

Note: Change is displayed in percentage points and based on unrounded percentages. Results may differ slightly from those that would be obtained using rounded figures. Bold font indicates a statistically significant change $(p<0.05)$.

Source: American Community Survey, 1-Year Estimates, 2009, 2012, and 2013

as their parents who need the resources to raise them, may be especially influential. Dollars spent in the short term may save money in the long run on reduced health care, safety net, and criminal justice costs. Finally, it is striking that most rural, black children are growing up in poverty, driven by rates in the South. Long-standing racial inequalities in this region may require targeted interventions to alter the fate of these children.
The statistics presented in this brief suggest an improving economic outlook for America's most vulnerable children. With nearly one in five children still living in poverty, however, there is a pressing need to improve the outcomes of these more than 16 million children. This is underscored by recognition that the poverty threshold is arbitrary and outdated, and is widely considered conservative in its assessment of families' real needs. Basic needs budgets that estimate 
a family's necessary expenses (including food, shelter, and utilities, but excluding luxuries like restaurant meals and child care outside of work hours) typically find that families need between 1.5 and 3.5 times the poverty threshold, depending on where they live, to cover the cost of a family's minimum day-to-day needs. ${ }^{6}$ Social safety net programs bridge a portion of this gap for some families. However, even when supplemental poverty measures (see Box 2) account for the value of non-cash assistance and post-tax transfer programs, children are still the age group most likely to be poor, with rates estimated at 18.0 percent (somewhat lower than the official measure suggests) in 2012. ${ }^{7}$ Many poor children are ineligible to receive all or some forms of social assistance because of restrictions with respect to citizenship and/or parents' or guardians' employment.

Parents face challenging obstacles to work including health or disability issues, access to child care, and transportation. In addition, many struggle to find sufficient employment to meet their family's needs. The nation's unemployment rate of 6.1 percent in August 2014 is dramatically lower than its postrecession peak of 10 percent in 2009, but it remains substantially higher than the 4.7 percent rate in 2007 before the Great Recession began. ${ }^{8}$ This rate, calculated only among those actively seeking work, masks the true employment situation for many Americans. In addition to those "discouraged" " workers who have given up finding work, countless others are working fewer hours than desired ${ }^{10}$ or are "stuck" in low-wage jobs with little room for advancement. These jobs may not offer sufficient hours for employees, and they often lack key employment related benefits like access to paid sick leave, health insurance coverage, and retirement savings plans. ${ }^{11}$ Additionally, many parents struggle with inconsistent hours, which make things like budgeting and securing child care difficult. Rural America has been hit especially hard by these challenges, as many historically vibrant communities decline in the wake of lost jobs in natural resource extraction and manufacturing. ${ }^{12}$ Places where middle class jobs were once available are now often plagued by a diminishing supply of low paying jobs in the service sector that make it difficult to make ends meet.

In this context, it is important to consider how America's poor children and families are affected by geographic variations in employment and by historical and cultural patterns of persistent poverty. It is also important to recognize that improvements in child well-being and further reductions in child poverty will likely require creative policy initiatives and the cooperation of the business sector, as well as the political will to improve the well-being of America's families.

\section{Data}

This analysis is based on estimates from the 2009, 2012, and 2013 American Community Survey. Tables were produced by aggregating information from detailed tables available on American FactFinder (http://factfinder2.census.gov/faces/nav/jsf/pages/index.xhtml). These estimates give perspective on child poverty, but they are based on survey data, so caution must be exercised in comparing across years or places. ${ }^{10}$ All differences highlighted in this brief and bolded in the tables are statistically significant $(p<0.05)$.

\section{Box 1: Definition of the Terms Rural, Suburban,} and Urban

Data for this brief are derived from the American Community Survey, which locates each address as being within one of several geographic components. As used here, "urban" designates households in the principal city of a given metropolitan statistical area, and "suburban" includes those in metropolitan areas, but not within the principal city of that area. "Rural" consists of the addresses that are not within a metropolitan area. 


\section{Box 2: A Dated Poverty Measure, and a New} Alternative

We use official poverty rates to compare child poverty across places, providing a consistent method for assessing the adequacy of families' incomes for meeting children's needs. However, the official poverty measure has important limitations. The measure is dated, relying on a foodspending-based formula established over fifty years ago to calculate annual poverty rates. It does not consider how work-related expenses (such as transportation and child care), in-kind assistance (for example, the Supplemental Nutrition Assistance Program, also known as food stamps), medical costs (such as insurance premiums), posttax transfers (for example, the Earned Income Tax Credit), or geographic differences in the cost of housing impact families' resources and expenses. ${ }^{13}$ The Census Bureau began producing an alternate measure, the Research Supplemental Poverty Measure, in 2009. It is an updated and more nuanced alternative that considers both the aforementioned expenses and assets when calculating poverty rates. When updates to this measure are released later in the fall of 2014, we will compare these newly measured poverty rates to the official poverty rates, and consider how these alternate calculations influence our understanding of the landscape of poverty.

\section{End notes}

1. New Hampshire's child poverty rate is statistically lower than all other states but no different from North Dakota.

2. Jeanne Brooks-Gunn, Greg J. Duncan, and Nancy Maritato, "Poor Families, Poor Outcomes: The Well-Being of Children and Youth," Chapter 1 in Consequences of Growing Up Poor, edited by Greg J. Duncan and Jeanne Brooks-Gunn (New York: Russell Sage Foundation, 1997).

3. For a review of this literature, see Sebastian J. Lipina and Michael I. Posner, "The Impact of Poverty on the Development of Brain Networks," Frontiers in Human Neuroscience, vol. 6 (2012).

4. Brooks-Gunn, Duncan, and Maritato, "Poor Families, Poor Outcomes."

5. Authors' calculation of 2007 American Community Survey data, available upon request.

6. Kinsey Aldon Dinan, "Budgeting for Basic Needs: A Struggle for Working Families," National Center for Children in Poverty, Mailman School of Public Health: Columbia University (2009).

7. Kathleen Short,"The Research Supplemental Poverty Measure: 2012," P60-247, Current Population Reports, U.S. Census Bureau, November 2013. Note that 2013 estimates will be available later in 2014 .

8. See http://data.bls.gov/timeseries/LNS14000000.

9. See the most recent Bureau of Labor Statistics "Economic News Release," Table A-16.

10. Rebecca Glauber, "Wanting More But Working Less: Involuntary Part-Time Employment and Economic Vulnerability," Issue Brief No. 64 (Durham, NH: Carsey Institute, 2013).

11. Arne L. Kalleberg, Good Jobs, Bad Jobs: The Rise of Polarization and Precarious Employment Systems in the United States, 1970s-2000s (New York: Russell Sage Foundation, 2011).

12. For a detailed summary of rural employment trends over the past decade, see Tom Hertz et al., "Rural Employment Trends in Recession and Recovery," ERR-172, U.S. Department of Agriculture, Economic Research Service, August 2014.

13. For a detailed description of the differences between official and supplemental poverty measures see Kathleen Short, "The Research Supplemental Poverty Measure: 2012," P60-247, Current Population Reports, U.S. Census Bureau, November 2013. 


\section{About the Authors}

Beth Mattingly is director of research on vulnerable families at the Carsey School of Public Policy and a research assistant professor of sociology at the University of New Hampshire (beth.mattingly@unh.edu).

Jess Carson is a vulnerable families research scientist at the Carsey School of Public Policy at the University of New Hampshire (jessica.carson@unh.edu).

Andrew Schaefer is a vulnerable families research associate at the Carsey School of Public Policy and a doctoral candidate in sociology at the University of New Hampshire (andrew.schaefer@unh.edu).

\section{A cknow led g ments}

The authors thank Paul Anskat and Jennifer Clayton for research assistance, Yumiko Aratani at Columbia University's National Center for Children in Poverty, Barbara Cook, Michele Dillon, Michael Ettlinger, Kenneth Johnson, Laurel Lloyd, and Amy Sterndale at the Carsey School of Public Policy for their assistance, comments, and suggestions.

\section{TI University of New Hampshire Carsey School of Public Policy}

The Carsey School of Public Policy conducts policy research on vulnerable children, youth, and families and on sustainable community development. We give policy makers and practitioners timely, independent resources to effect change in their communities.

This work was supported by the Annie E. Casey Foundation, the W. K. Kellogg Foundation, and anonymous donors.

Huddleston Hall 73 Main Street • Durham, NH 03824

(603) 862-2821

TTY UsERS: DIAL 7-1-1 OR 1-800-735-2964 (RELAY N.H.)

carsey.unh.edu 